\title{
Recent Research Trends of Flexible Piezoelectric Nanofibers for Energy Conversion Materials
}

\author{
Sang Hyun Ji and Ji Sun Yun ${ }^{\dagger}$
}

Energy \& Environment Division, Korea Institute of Ceramic Engineering \&Technology, Jinju 52851, Korea

\section{에너지 변환 소재용 플렉서블 압전 나노섬유 연구 개발 동향}

\author{
지상현, 윤지선 ${ }^{\dagger}$ \\ 한국세라믹기술원, 에너지환경본부
}

(Received May 23, 2019, Revise June 10, 2019; Accepted June 10, 2019)

\begin{abstract}
s
Wearable electronic devices with batteries must be lightweight, flexible and highly durable. Most importantly, the battery should be able to self-generate to operate the devices without having to be too frequently charged externally. An eco-friendly energy harvesting technology from various sources, such as solar energy, electromagnetic energy and wind energy, has been developed for a self-charging flexible battery. Although the energy harvesting from such sources are often unstable according to the surrounding environment, the energy harvesting from body movements and vibrations has been less affected by the surrounding environment. In this regard, flexible piezoelectric modules are the most attractive solution for this issue, because they convert mechanical energy to electrical energy and harvest energy from the human body motions. Among the various flexible piezoelectric modules, piezoelectric nanofibers have advantages when used as an energy harvester in wearable devices, due to their simple manufacturing process with good applicability to polymers and ceramics. This review focused on diverse flexible piezoelectric nanofibers and discusses their applications as various energy harvesting systems.
\end{abstract}

Keywords: Piezoelectric, Nanofiber, Electrospinning, Energy harvesting

1. 서론

현재 전 세계는 과거부터 사용되어 왔던 화석 연료의
고갈과 화석 연료 사용으로 발생되는 온실가스 배출로 인 한 지구온난화와 같은 이상 기후 문제에 직면해 있다. 이 러한 문제를 극복하기 위해 연료고갈의 문제가 없고 친환 

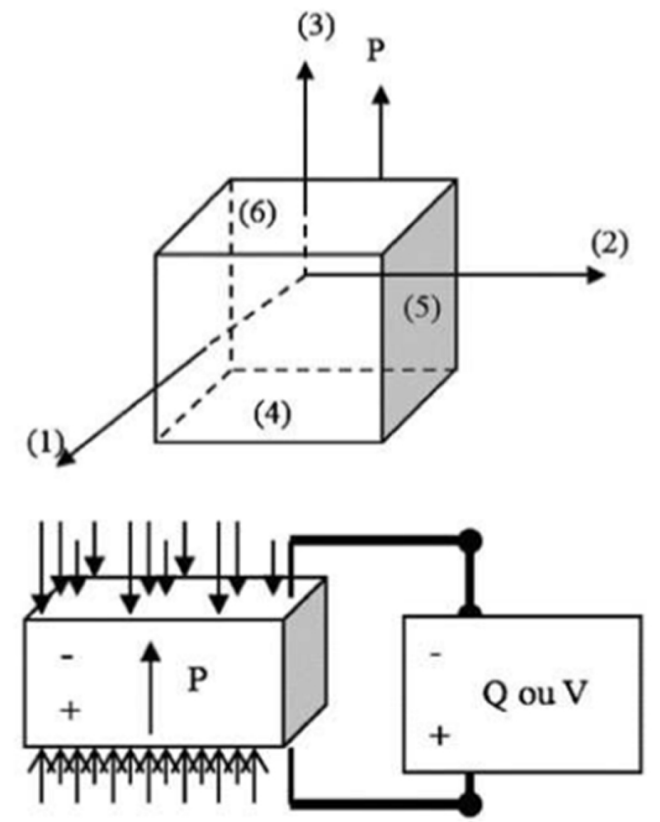

(a)

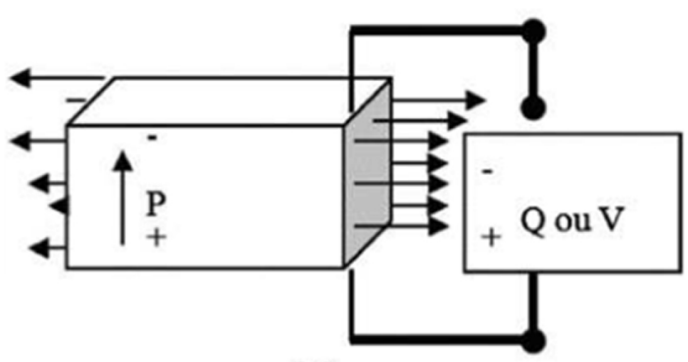

(b)

Fig. 1. Axes reference and the most usual operating modes for piezoelectric power generator: (a) longitudinal mode according to the direction and (b) transverse mode according to direction ${ }^{4}$.
경적인 에너지원인 태양, 수력, 풍력 등을 통한 에너지 변 환에 대한 개발에 관한 연구가 활발하게 진행되고 있다. 그러나 친환경적인 에너지원은 에너지로 변환하기 위해 주변 환경이 매우 중요하며 에너지원을 일상에서 사용 가 능하도록 변환 하는 장치의 설치 및 운용비용이 비싸다는 단점이 있다. 따라서 최근에는 조금 더 쉽게 에너지를 얻 을 수 있는 친환경 에너지 하베스팅 및 변환 기술이 개발 되어 에너지 변환을 조금 더 쉽게 할 수 있는 기술 개발이 이루어 지고 있다. 친환경을 사용한 에너지 하베스팅 기 술은 태양, 바람, 동물 움직임, 진동, 자동차의 폐열, 방 송 전파 등 주변에서 버려지는 에너지를 모아 전력으로 재활용하여 사용하는 기술이다 ${ }^{1-3)}$. 특히 다양한 에너지 하베스팅의 기술 중 압전 에너지 하베스팅 기술은 Fig. 1 과 같이 압전체에 인장력이나 압축력을 가하면 압전 물체 의 결정을 구성하는 분자 혹은 이온간에서 전기 쌍극자의 크기가 변화하며 전기장이 형성되는 원리로 전기가 발생 된다 ${ }^{4)}$. 이러한 이유로 바람 및 태양 등과 같은 외부 신 재 생에너지원이 제공되지 않는 상황에서도 미세한 움직임 에 의해 발생되는 진동, 굽힘 및 하중 등의 기계적 에너지 를 전기적 에너지로 변환할 수 있는 차세대 에너지 생성 소자로 주목 받고 있다. 따라서 주위 환경에 대한 영향을 최소화 하고 에너지원이 고갈될 문제가 없으며, 친환경적 인 장점이 있기 때문에 많은 연구자들이 압전 에너지 하 베스팅 기술을 개발하고 있다. Fig. 2는 실제 웨어러블 디바이스 구동을 위한 필요한 소비전력을 보여주고 있다. 웨어러블 디바이스 응용 분야에서 가장 많이 활용되고 있 는 센서 및 무선 통신 소자에 대하여 다음과 같이 나타낸 것처럼 마이크로와트급의 온도 센서 $(0.3 \sim 0.4 \mu \mathrm{W})$, 압력

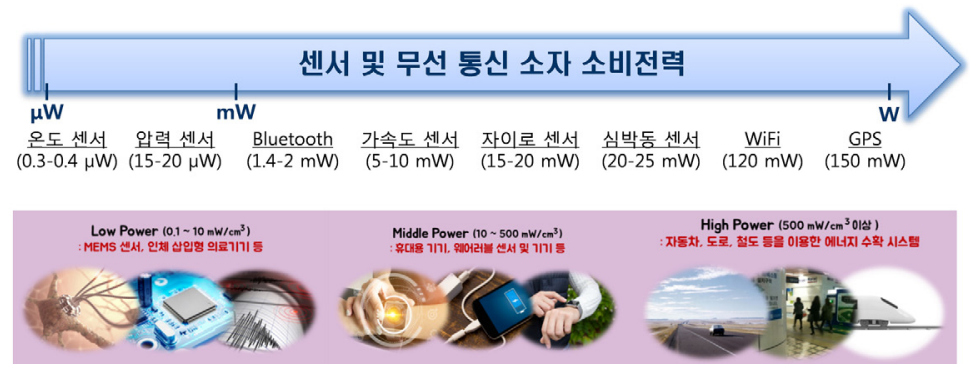

Fig. 2. Required power consumption according to application fields of wearable devices. 
센서(15 20 $\mu \mathrm{W})$ 부터 밀리와트급의 블루투스(1.4 2.0 $\mathrm{mW})$, 자이로 센서(15 20 mW), GPS(150 mW) 등의 범 위를 갖고 있는 것으로 조사되었다. 이는 웨어러블 디바 이스의 전원기술로써 활용되기 위해서는 최소 수에서 수 십 마이크로와트 수준의 출력이 필요하다는 것을 나타내 고 있으며, 이러한 low power 및 middle power 영역에 서는 압전 에너지 하베스팅이 적합한 것으로 판단된다. 이러한 점에서 앞으로도 가장 넓은 분야에서 상용화 될 가능성이 있는 기술로 잘 알려져 있다.

기존에 개발된 압전 에너지 하베스팅을 이용한 에너지 변환 소재는 주로 벌크(bulk) 형태로 개발되어 사용되고 있다. 그러나 압전체에서 발생되는 전기에너지는 압전체 에 외력을 가해 전기를 생성하는 특성상 오랜 시간 사용 하면 압전 소자의 특성상 내구성 부분에서 한계가 발생된 다. 또한 최근에 개발되고 있는 웨어러블 및 생체 삽입형 전자 디바이스들의 에너지원으로 사용되기 위한 압전 에 너지 변환 소재의 경우 유연성이 요구된다. 이러한 니즈 를 충족시키기 위해서는 획기적인 새로운 형태인 플렉서 블한 소재를 이용하여 플렉서블 압전 하베스팅 기술을 이 용한 에너지 변환기술이 필요하며 전 세계적으로 플렉서 블 압전 에너지 변환 소재에 대한 연구가 많이 이루어지 고 있다5-6). 또한 전자기기가 날로 발전하면서 과거 부피 가 크고 무거운 전자기기의의 형태에서 최근에는 휴대성 이 좋고 가벼운 웨어러블 전자기기의 수요가 증가되어 웨 어러블 디바이스 개발의 연구가 활발하게 진행되고 있다. 특히 최근 산업계에서는 웨어러블 소자는 향후 스마트폰 시장을 대체할 유력한 산업으로 인식되고 있다. 현재까지 웨어러블을 기반으로 한 제품으로는 구글에서 최초로 개 발되어 시장에 출시된 안경이나 애플사의 스마트 시계, 전자섬유로 직조된 패치형 직물/의류 제품, 신체에 탈 부 착하거나 생체에 삽입을 통해 기능을 유지하는 센서 제품
등이 있닥) 현재 출시된 전자기기들을 구동하기 위해서 는 현재 리튬 이온 배터리를 충전하여 사용하고 있지만 충전의 불편함과 부피, 무게 등의 다양한 문제로 인해 자 가 충전이 되고 높은 에너지 변환 효율을 가지는 플렉서 블 에너지 변환 소재에 대한 연구 또한 같이 증가되고 있 다. 자가 충전이 되고 높은 에너지 변환 효율을 가지는 플 렉서블 에너지 변환 소재는 현재 세계 각국 연구진들이 나노와이어(nanowire), 나노섬유(nanofiber) 및 나노와 이어 어레이(nanowire array)와 압전 고분자를 플라스 틱 기판에 구현하여 개발하고 있으며, 개발된 플렉서블 기반의 압전 에너지 생성 및 변환 소자인 나노발전소자 (nanogenerator)에 대한 연구가 진행되고 있다-10). 그 중 나노섬유는 제작이 쉽고 운용 비용이 적게 들며 높은 비표면적을 가지고 다양한 세라믹과 합성에 용이하여 다 양한 성능을 나타낼 수 있는 장점이 있다. 뿐만 아니라 나 노섬유 대면적이 다른 플렉서블 소재에 비해 쉽게 될 수 있기 때문에 나노섬유를 이용한 플렉서블 압전 나노섬유 에너지 변환 소재에 대한 연구는 현재까지도 가장 많이 활발하게 진행되고 있다.

본 원고에서는 플렉서블 압전 에너지 변환 소재로 주로 사용되는 압전 나노섬유의 제조 방법 및 압전 나노섬유를 이용한 플렉서블 압전 에너지 하베스팅 모듈의 연구 결과 를 고찰하고 다양한 적용분야를 소개하고자 한다.

\section{2. 본론}

\section{1 나노섬유}

\subsection{1 전기방사를 통한 나노섬유 제조 원리}

섬유 산업에서는 Table 1 과 같이 나노섬유는 일반적으 로 외경이 $1000 \mathrm{~nm}$ 이하이고 종횡비(길이와 폭의 비율)

Table 1. Definition of nanofibers, nanorods, nanoribbons and nanowires ${ }^{11}$.

\begin{tabular}{|c|c|c|c|}
\hline Nanostructure & Section Type & Diameter (nm) & Aspect Ration \\
\hline Nanorods & Solid & $\langle 100$ & $3-5$ \\
\hline Nanowires & Solid & $\langle 100$ & $>1,000$ \\
\hline Nanofibers & Solid or hollow & $\langle 1,000$ & $>50$ \\
\hline Nanoribbons & Solid & $\begin{array}{c}\text { Thickness }\langle 50 \\
\text { Width } 100-1.000\end{array}$ & $>50$ \\
\hline
\end{tabular}




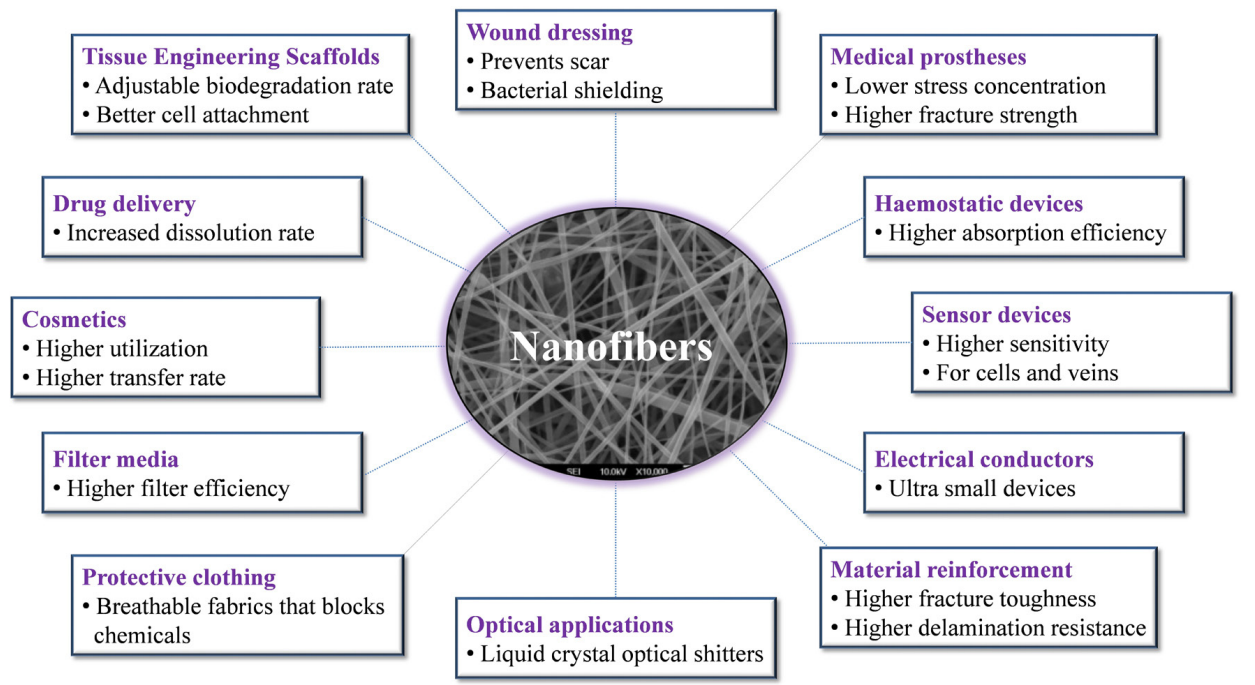

Fig. 3. Application of nanofibers

가 50 을 초과하는 원통형 구조로 정의된다 ${ }^{11)}$. 현재까지 탄소, 세라믹, 유리, 금속 및 합금, 유기물, 반도체 및 복 합재등 몇 가지 유형의 나노섬유가 개발되었으며, 적용분 야는 Fig. 3 와 같이 센서, 필터, 광학, 화장품 그리고 약 물전달 등으로 매우 다양하다. 나노섬유를 제작하는 방법 으로는 자기조립과 전기방사 방법이 가장 널리 사용되고 있지만, 자기조립 방법은 주로 유기 태양전지 분야로 그 사용이 국한되어 있는 반면 전기방사 방법은 사용 분야가 국한되지 않고 다양한 분야에서 사용되어 지기 때문에 가 장 보편적으로 섬유를 제조하는 방법으로 알려져 있다. 전기방사 방법은 Fig. 4과 같은 구조의 전기방사 장치를 이용하여 섬유를 제작하는 기술로 크게 방적돌기, 접지된 집전판, 고전압 전원장치, 실린지 펌프로 구성되어 있다. 나노섬유를 제조하기 위해서 준비된 전구체 용액이 담긴 실린지를 방적돌기 역할을 하는 금속 재질의 노즐에 연결 하여 실린지 펌프에 고정시킨다. 그리고 노즐에 고전압을 가하면서 실린지 펌프를 일정한 속도로 분사한다. 이 때 금속 재질의 노즐 팁 끝에 양전하로 하전된 용액 방울이 맺히게 된다. 이 용액 방울 표면의 양전하 간의 정전기적 척력과 외부 전기장에 의한 전기력이 반구형 용액 방울을 테일러콘(taylor cone)이라는 원뿔 모양으로 만든다. 이 테일러콘에 높은 전압을 인가하여 용액의 표면 장력을 넘

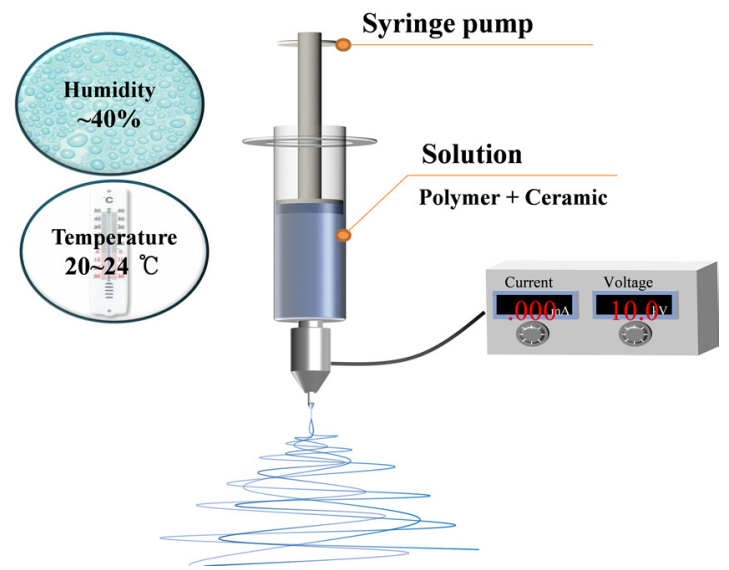

Fig. 4. Schematic diagram of electrospinning process.

어설 때, 테일러콘 끝에서 jet이 분사되어 나오게 되고, 방출된 jet은 초기에는 곧게 신장되며 분사하다가 특정 지점부터 whipping 모션을 취하며 분사된다. 분사되는 jet이 집전판에 닿기 전까지 jet에 포함된 용매는 모두 휘 발되어 결국 집진판에는 용매가 모두 증발된 나노섬유가 모이게 된다.

\subsection{2 전기방사 공정 변수}

전기방사 방법으로 나노섬유를 제작할 때 공정 방법은 매우 간단하나 공정 시 고려되어야 할 변수들은 매우 다 
CERAMIST

특 집 ㅁㅁ 지상현, 윤지선

양하다. 가장 대표적인 변수들은 전기방사 전구체 용액의 점도, 인가 전압, 방사 속도, 방사 거리, 용매의 휘발성, 니들 사이즈, 전기방사 시 온도 및 습도 등이 있으며, 나 노섬유를 연속적으로 균일하게 제조하기 위해서는 위 변 수들을 유기적으로 고려된 최적화 조건이 필요하다.

특히 가장 중점적으로 고려해야 할 것은 전기방사를 하 기 위한 전구체 용액의 점도이다. 전구체 용액의 점도는 섬유 방사 시 섬유의 형상과 관련이 있다. 전구체에 포함 된 고분자에 의해 결정되는 점도가 너무 낮으면 즉, 고분 자의 양이 충분하지 않으면 용액에서의 고분자의 사슬 엉 킴이 부족하여 분자 간 인력이 충분하지 못하기 때문에 분사 시 jet이 표면 에너지를 최소화하기 위해 여러 개의 방울로 나뉘어진다. 따라서 전기방사 시 연속성 있는 나 노섬유의 형상을 얻기 힘들다. 반대로 전구체 용액의 농 도가 너무 높을 경우에는 응력완화 시간이 너무 길어져 같은 응력에도 쉽게 파괴게 일어나 jet이 잘 끓어지게 되 고 전기방사 시 용매 증발과정에서 남은 고분자가 니들을 막는 현상이 발생되어 원활한 전기방사 되지 않는다. 따 라서 전구체 용액의 경우 고분자 비율 최적화를 통한 최 적의 농도로 조절해야 안정적인 연속상의 섬유를 얻을 수 있다. 또한 고분자의 종류에 따라 사용하는 용매가 달라 지게 되므로, 나노섬유의 최종 사용 목적에 따라 고분자 와 용매를 각각 선택해야 한다.

\section{2 압전 나노섬유}

\subsection{1 압전 고분자 나노섬유}

일반적으로 압전 나노섬유에 사용되는 압전 고분자는 $\mathrm{PVDF}$ (polyvinylidene-fluoride)로고분자 사슬이 규칙 적으로 배열되어 있는 crystallite와 무질서하게 배열되 어 있는 영역(amorphous region)이 공존하고 있는 고분 자이다. 고분자 사슬이 규칙적으로 배열된 crystallite 영 역은 대개 주로 $\alpha$ 상 혹은 $\beta$ 상의 형태로 존재하게 된다. $\beta$ 상으로 존재하는 영역은 강유전 구역(ferroelectric domain)에 해당하며, $\alpha$ 상으로 존재하는 영역은 상유전 구역(paraelectric domain)에 해당한다. 강유전 구역은 전기적 쌍극자(electric dipole)가 한 방향으로 정렬되어
있어 압전 특성을 보여주나, 상유전 구역은 전기적 쌍극 자의 합이 0이 되어 압전 특성을 나타내지 않는다. 따라 서 PVDF 고분자는 강유전 구역들의 쌍극자 방향을 정렬 하기 위한 분극 공정을 필요로 한다. 일반적으로 벌크형 압전체는 제조 후 높은 전압으로 분극공정을 진행해야 쌍 극자의 방향이 정렬되지만 나노섬유로 제작된 $\mathrm{PVDF}$ 고 분자는 전기방사 시 높은 인가 전압에 의해 절렬되기 때 문에 별도의 분극 공정을 추가로 진행하지 않아도 되는 장점이 있다.

이러한 PVDF 고분자의 압전 특성을 보다 더 높이기 위 해서 많이 사용되는 고분자로는 $\mathrm{VDF}$ 단분자와 trifluoroethylene(TrFE) 단분자의 중합체로 이루어진 $\mathrm{P}(\mathrm{VDF}-\mathrm{TrFE})$ 가 있다. $\mathrm{PVDF}-\mathrm{TrFE}$ 고분자는 $\mathrm{PVDF}$ 보다 상대적으로 높은 결정성을 나타내게 되어 더 높은 압전특성을 보이게 된다 ${ }^{12)}$. 뿐만 아니라 최근에는 더 높 은 압전 특성을 가지는 $\mathrm{P}(\mathrm{VDF}-\mathrm{TeFE})$ (Poly-Vinylidene Fluoride and Tetrafluoroethylene) 고분자를 개발하여 압전 섬유에서의 특성 극대화를 위한 연구가 계속 진행 중이다 ${ }^{13)}$

\subsection{2압전 세라믹 나노섬유}

세라믹 합성 압전 나노섬유를 제작하는 방법으로 가장 대표적인 방법으로는 졸-겔(sol-gel)용액을 전기방사하
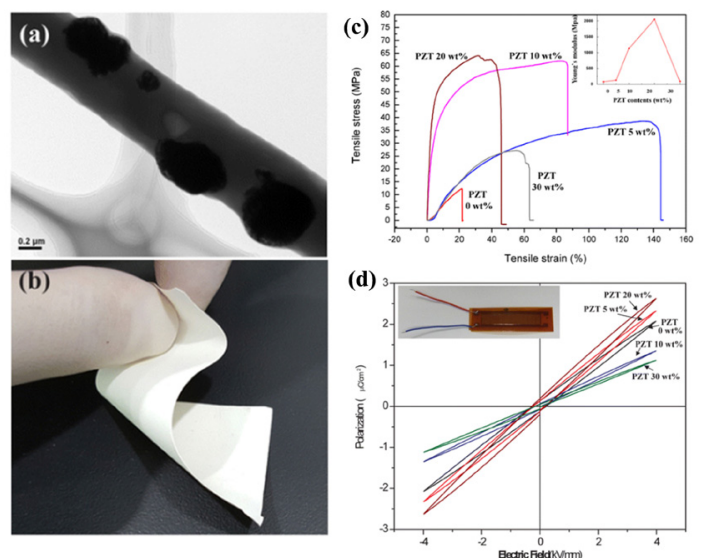

Fig. 5. (a) TEM image and (b) optical image of the PZT/PVDF nanofiber films with a PZT content of $20 \mathrm{wt} \%$. (c) Tensile stress-strain properties and (d) P-E hysteresis loops of PZT/PVDF nanofiber composite films prepared with different levels of PZT content ${ }^{(4)}$. 
여 고분자 섬유와 무기 전구체의 복합체 나노 섬유를 제 작하는 방법이다. 졸-겔 방법으로 방사된 섬유를 $400^{\circ} \mathrm{C}$ 이상의 고온으로 열처리를 하게 되면 나노섬유에 합성된 고분자가 열분해되며, 무기전구체는 결정화되어 다결정 금속산화물 구조체의 나노섬유가 제조된다. 2016년도에 는 한국세라믹기술원에서 PZT 압전 세라믹이 나노섬유 를 졸-겔 방법으로 개발에 성공하였다 ${ }^{14)}$. 제작된 PZT 압 전 나노섬유는 Fig. $5(\mathrm{a})$ 과 같이 나노섬유안에 세라믹이 박혀있는 구조이며, 소결을 통하여 PZT 결정구조가 형성 이되고 그를 둘러싸고 있는 고분자는 완전히 제거가 된 다. 이러한 소결공정을 통해 우수한 압전 특성을 가질 수 있다. 다만 Fig. $5(\mathrm{~b})-(\mathrm{c})$ 와 같이 세라믹의 함량이 지나 치게 높으면 압전 나노섬유의 강도 및 압전 특성이 줄어 드는 경향을 보이므로 조성을 최적화할 필요가 있다.

\subsection{3압전 세라믹/고분자 복합 나노섬유}

압전 고분자 나노섬유는 압전 고분자 자체가 압전 세라 믹 대비 압전 특성이 현저하게 낮다는 재료적 한계가 있 다. 이에 반해 압전 세라믹 나노섬유는 압전 세라믹의 결 정 구조를 얻기 위해 전기 방사 후, 반드시 소결 공정을 거치는데 이러한 소결 공정 이후에는 유연성을 잃는 다는 문제점이 있다. 이러한 단점들을 극복하고자 최근 연구에 서는 우수한 압전 특성을 가지는 압전 세라믹을 고분자와 복합화하여 압전 나노섬유를 제조하는 연구가 진행되고 있다. 2012년 이후에는 나노 발전기의 발전성능 향상을 위해 높은 압전 상수를 가지는 페로브스카이트 결정구조 의 압전 세라믹소재를 이용한 연구가 $\mathrm{BaTiO}_{3}$ 나노입자 ${ }^{15}$ 를 사용하여 시작되었으며, $(\mathrm{K}, \mathrm{Na}) \mathrm{NbO}_{3}{ }^{16,17}, 0.5\left(\mathrm{Ba}_{0.7}\right.$ $\left.\mathrm{Ca}_{0.3}\right) \mathrm{TiO}_{3} 0.5 \mathrm{Ba}\left(\mathrm{Zr}_{0.2} \mathrm{Ti}_{0.8}\right) \mathrm{O}_{3}(\mathrm{BCTZ})^{18)}$ 및 $\mathrm{BaZr}_{\mathrm{x}} \mathrm{Ti}_{1-}$ ${ }_{\mathrm{x}} \mathrm{O}_{3}(\mathrm{BZT})^{19)}, \mathrm{PZT}\left(\mathrm{Pb}\left(\mathrm{Zr}_{0.53} \mathrm{Ti}_{0.47}\right) \mathrm{O}_{3}\right)^{20)}$ 나노입자를 압전 나노섬유에 적용한 연구가 진행되고 있다. 세라믹을 나노 섬유에 합성하여 전기방사를 통해 제작된 섬유는 아래 Fig. 6과 같이 섬유 안에 세라믹 입자가 고르게 존재하는 것을 알 수 있다21). 이렇게 제작된 압전 세라믹/고분자 복 합 나노섬유의 대표적인 결과로 $\mathrm{PZT} / \mathrm{PVDF}-\mathrm{TrFE}$ 압전 나노섬유가 개발되었다22) 개발된 합성된 $\mathrm{PZT} / \mathrm{PVDF}-$ $\mathrm{TrFE}$ 압전 나노 섬유는 기존의 PVDF-TrFE 압전 섬유

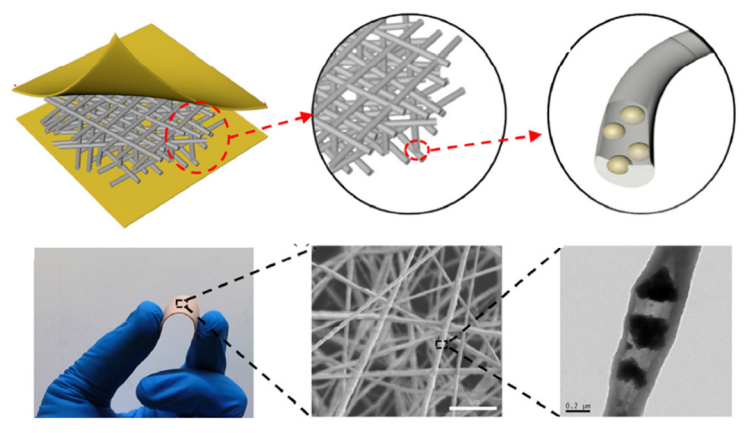

Fig. 6. A schematic diagram, SEM and TEM images of piezoelectric ceramic composite nanofibers ${ }^{21}$.

에 비해 출력 전압이 약 $20 \%$ 정도 증가된 결과가 보고 되 었다. 이는 기존의 PVDF- TrFE 고분자만을 이용하여 압전 나노섬유를 제조하였을 때보다 압전 세라믹을 복합 화하여 압전 나노섬유를 제조하는 것이 더 높은 압전 특 성을 가지는 것을 의미한다. 또한 PZT 압전 나노섬유 이 외에도 무연 압전 세라믹인 $\mathrm{KNN}$ 압전 나노섬유 ${ }^{23)}$, $\mathrm{BNT}$ 압전 나노섬유 ${ }^{24)}$ 등을 전기방사 방법으로 제조에 성공하 여 우수한 출력 특성을 보고되었다. 최근에는 압전 세라 믹이 복합화된 압전 나노섬유의 전기 방사 형태에 따라 나노섬유를 기존의 랜덤한 형태에서 정렬된 상태의 나노 섬유로 제작하여 압전 나노섬유의 특성을 증가시켜 실생 활에 여러 곳에 사용할 수 있도록 하고 있다 ${ }^{25)}$.

\section{3 압전 나노섬유 기반 플렉서블 압전 에너지 변환 모듈}

압전 나노섬유 기반 플렉서블 압전 에너지 변환 모듈에 서 전기에너지 생성 원리는 Fig. 7와 같다. 압전 소자는 발전 성능을 극대화하기 위해 압전 소재 내부에 존재하는 도메인(동일한 방향성을 가지는 쌍극자들로 구성된 영 역)을 동일한 방향으로 배열하기 위한 과정인 분극 공정 을 실시한다. 분극 처리된 플렉서블 압전 발전 소자의 굽 힘 운동시 압전 소재는 인장 응력에 의한 기계적 변형이 일어나고 이 때 압전 포텐셜이 형성되어 전극 내의 자유 전자들이 외부 회로를 통해 흘러가게 되어 전기에너지가 발생된다. 이후 굽임 운동을 위해 인가하였던 힘이 제거 되면 압전체 내에 응력이 제거되면 상부 전극에 축적된 


\section{특 집 ㅁㅁ 지상현, 윤지선}

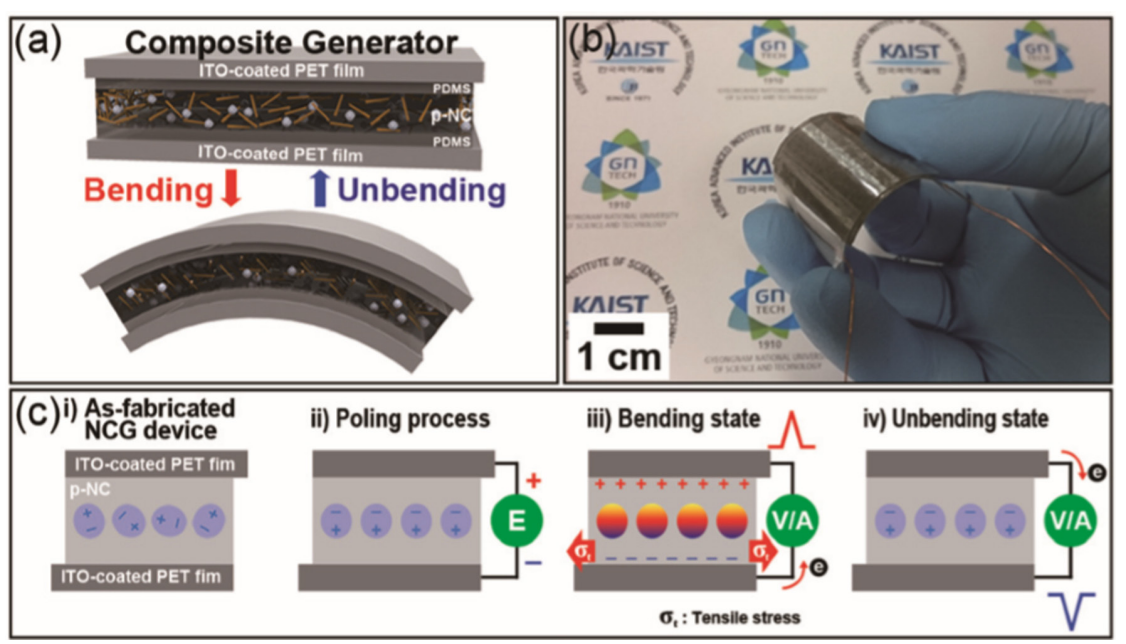

Fig. 7. Schematics of the energy generation mechanism of the flexible piezoelectric device ${ }^{17}$.

a)

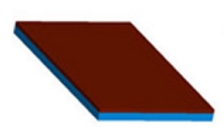

i) Si substrate and PR

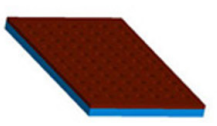

ii) Photolithography

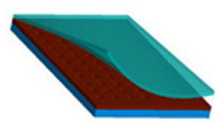

iii)PDMSMWCNT film patt

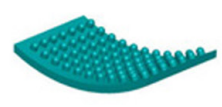

iv) PDMS/MWCNT film
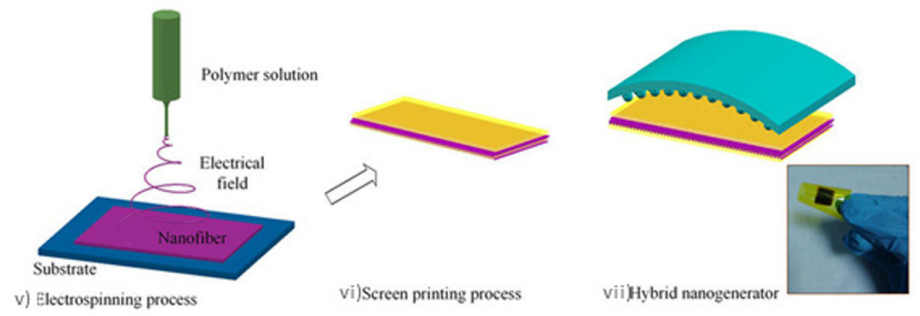

b)
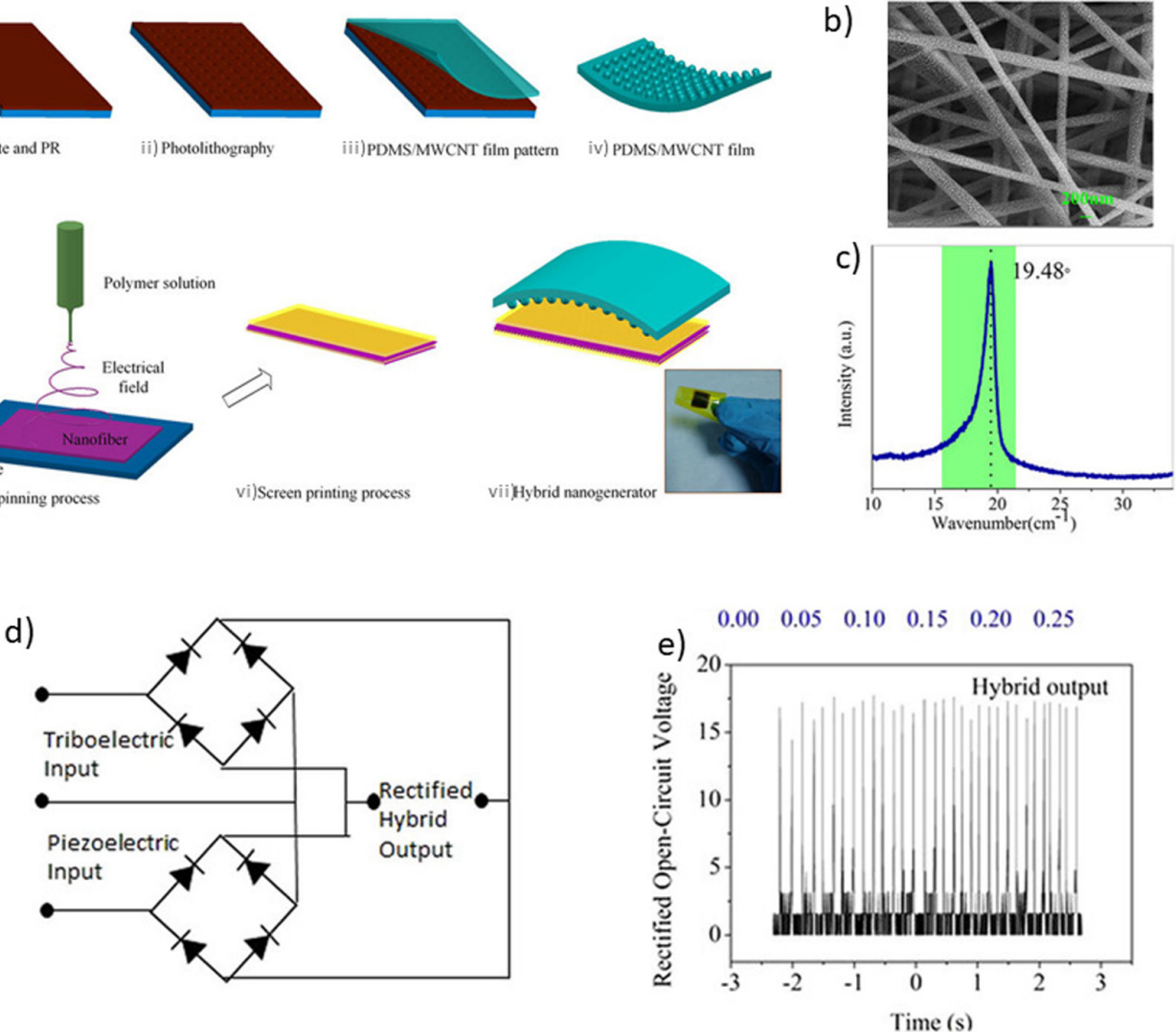

Fig. 8. Hybrid NG with a electrospun P(VDF-TrFE) nanofibers based piezoelectric NG and PDMS/MWCNT based triboelectric NG. (a) Schematic structure of the hybrid NG. (b) Electrospun P(VDF-TrFE) nanofibers. (c) XRD for as-synthesized nanofibers. (d) Electric connection and rectifying circuit for hybrid NG. (e) Rectified voltage output. ${ }^{26)}$ 
전자들이 처음 위치인 하부 전극으로 이동하게 되어 반대 극성의 전기 에너지가 측정된다. 이에 세라믹 압전 나노섬 유를 에너지 변환 소재로 사용하기 위해서는 압전 나노섬 유에 적합한 형태의 모듈에 접목 시켜 줘야 한다. 따라서 최 근에는 다양한 형태의 압전 나노섬유 기반의 유연한 모듈 이 개발되고 있다. Fig. 8은 PDMS(polydimethylsiloxane) 에 일정한 패턴을 설계하여 압전 나노섬유를 적용시킨 모 듈로 최대 출력 전압이 약 $17 \mathrm{~V}$ 의 우수한 특성을 나타내는 것을 확인할 수 있었다 ${ }^{26)}$. 이는 플렉서블한 $\mathrm{PDMS}$ 를 에 너지 변환 소재 기판으로 활용하여 압전 나노섬유에 외력 이 가할 때 일정한 패턴에 의해 외력이 더 집중적으로 나 노섬유에 작용되어 압전 효과 외에도 모듈의 표면 재료에 의한 마찰전기(triboelectric)가 추가 작용하기 때문이다. 압전 나노섬유 모듈의 구조뿐 아니라 최근에는 압전 나노 섬유의 모듈은 출력 값은 전극의 영향을 많이 받는 것으 로 보고되고 있다. 일반적으로 압전 나노섬유 모듈의 전 극은 상부 전극과 하부전극이 일정한 패턴 없이 전면 전 극을 사용하는 $\mathrm{d}_{31}$ 모드와 깍진낀 전극을 사용하는 $\mathrm{d}_{33}$ 모 드가 있는데 이런한 전극 패턴에 따라 출력 전압이 바뀌 는 것이 보고되었다 ${ }^{27)}$. 따라서 많은 연구진들은 전극의 형태 혹은 전극 사이 간격, 전극의 너비에 따른 출력량 변

(a)
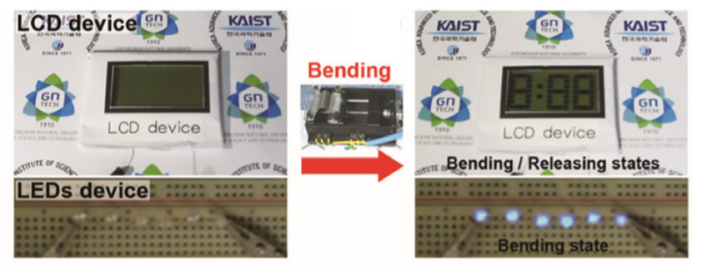

(b)
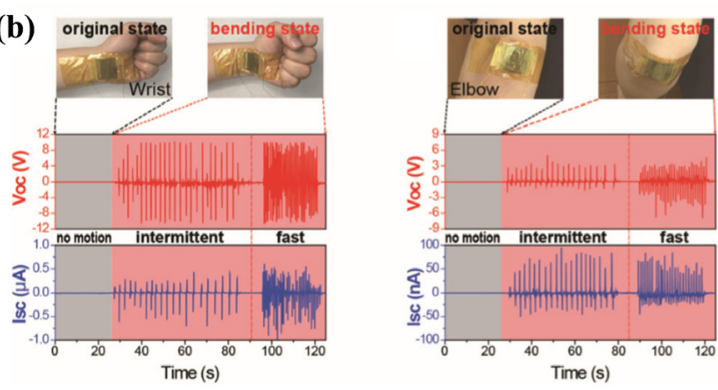

Fig. 9. (a) Captured images of commercial electronic devices (LCD and LEDS) operated by the electricity generated from BCTZ nanoparticles-based flexible energy harvester and (b) recorded electrical signals from a motion sensor based on a piezoelectric energy device ${ }^{18)}$.
화량에 따른 출력 특성을 조사하였다. 가장 최근에는 플 렉서블한 성질을 극대화하고 웨어러블 기기에 착용시 이 질감을 줄여주는 압전 나노 실(yarn)형태로 한국세라믹 기술원에서 개발되었다 ${ }^{28)}$. 또한 최근 서울대, 연세대, 영 남대 그리고 한국세라믹기술원은 공동연구를 통하여 실 제 압전 나노섬유를 yarn으로 제조 후 직조하여 천 형태 의 플렉서블 압전 발전 소자를 개발하고 있으며 향후 3 년 안에 실제 등산복과 같은 스포츠 의류에 적용되어 사용될 것으로 판단된다.

\section{4 압전 나노섬유 기반 플렉서블 압전 에너지 변환 모듈의 활용}

압전 나노섬유 기반 플렉서블 압전 에너지 변환 모듈을 실생활에 적용하기 위한 시도는 오랫동안 계속되어 왔다. 초기 연구에서는 플렉서블 압전 나노섬유를 포함하고 있 는 모듈의 측정 전압 및 전류 값이 낮아 저전력 전자소자 를 구동하기는 어려워 정류 및 축전과정을 통해 전력원으 로 사용될 수 있다는 가능성만을 보여 주었다. 하지만, 압 전 나노섬유의 압전 특성 향상을 위한 조성 설계 및 모듈 최적화 연구를 통하여 플렉서블 압전 나노섬유의 압전 특 성 향상 연구가 이루어지면서, 압전 발전 성능이 크게 향 상된 다양한 형태의 플렉서블 압전 발전 소자의 연구결과 보고되기 시작하였다. Fig. 9(a)는 2016년 KAIST 김도 경 교수 연구팀에서 발표한 $\mathrm{BCTZ}$ 압전 나노섬유 소재 기

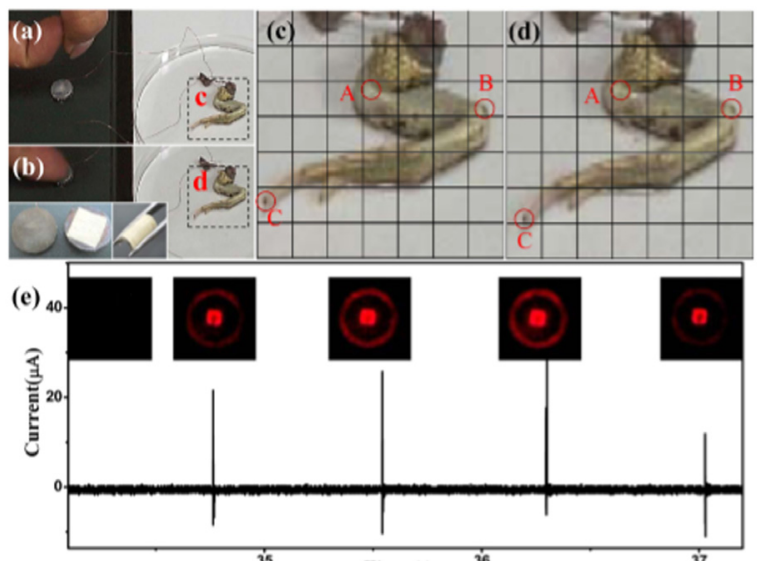

Fig. 10. Photograph showing the stimulation of frog's sciatic nerve by electrical energy harvested from PZT nanowire array $^{29)}$. 


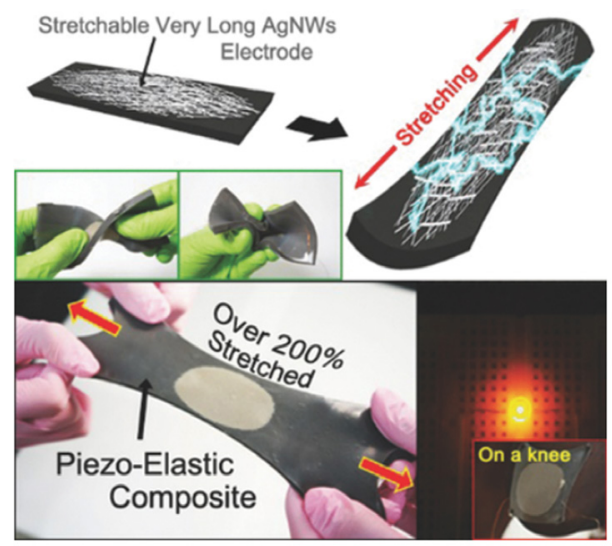

Fig. 11. Photographs and the generated output signals of stretchable nanocomposite generator attached onto a stocking ${ }^{30)}$.

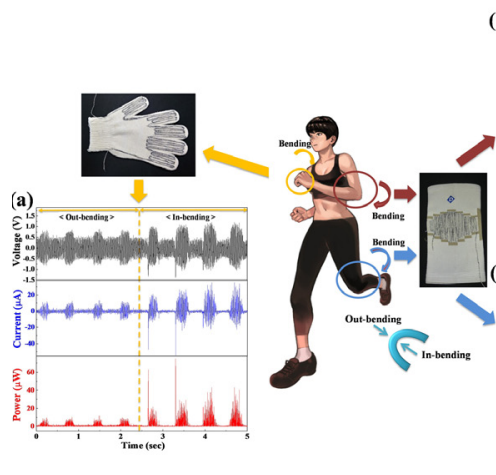

(d)
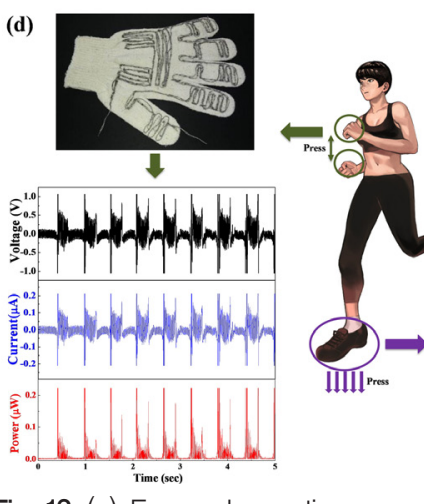

(e)
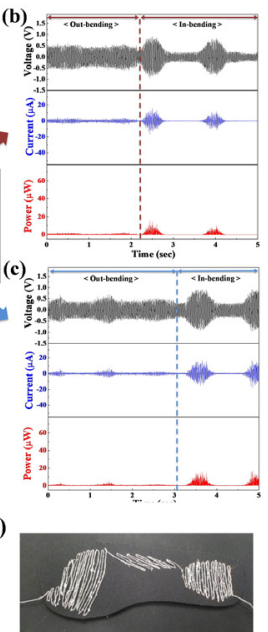

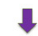
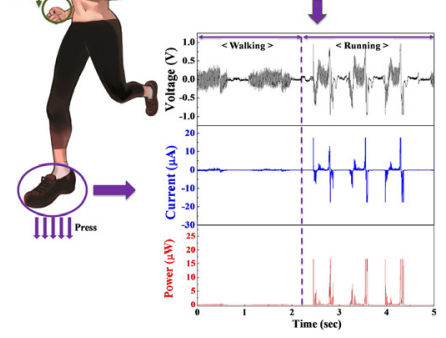

Fig. 12. (a) Energy harvesting properties according to bending finger movements as a cotton glove stitched in the finger parts. Energy harvesting properties according to bending (b) elbow and (c) knee movements as the guard stitched in the elbow and knee parts, respectively. (d) Energy harvesting properties according to clapping movements as a cotton glove stitched in the effective area, and (e) energy harvesting properties according to walking and running movements as a shoe insole stitched in the effective area ${ }^{28)}$.
반의 압전 발전 모듈을 이용해 응용 실험을 수행한 결과 로, 반복적인 굽힘에 의해 생성된 전력을 이용해 LCD 및 $\mathrm{LED}$ 전자소자들을 실시간으로 구동한 것을 보여주고 있 다 ${ }^{18)}$. 또한, Fig. 9(b)와 같이 압전 나노섬유로 제작된 압 전 발전 모듈로 제작하여 손목에 부착 후 손목의 굽힘 움 직임에 따른 출력전압 및 전류의 상대적인 값 차이를 이 용해 움직임 센서로의 적용 가능성을 확인한 실험을 수행 하였다. Fig. 10은 PZT 압전 나노섬유를 이용해 제작된 압전 발전 소자를 이용한 실험 결과로, 소자의 일정한 압 력을 통해 전기적 신호(209V)를 발생시켜 개구리의 좌골 신경에 전기적으로 자극하는데 사용하여 의학분야로의 적용 가능성을 보여준 결과이다 ${ }^{29}$. Fig. 11은 플렉서블한 압전 발전 소자를 이용하여 의류에 부착하여 신체 움직임 에 따른 전압 출력량 측정 실험이다 ${ }^{30)}$. 본 실험은 압전 나 노섬유 안에 압전 세라믹 입자가 복합화된 압전 나노섬유 복합체의 상/하부에 인장 가능한 은 $(\mathrm{Ag})$ 기반의 전극을 이용하여 모듈이 약 $200 \%$ 까지 늘려도 기계적 안정성을 보이면서 약 $4 \mathrm{~V}$ 의 전압과 $500 \mathrm{nA}$ 의 전류를 생성할 수 있 는 소자를 개발하여 출력 값 측정 실험을 실시하였다. 압 전 나노섬유 기반의 섬유 모듈이 부착된 스타킹을 착용하 고 인체 무릎을 굽힐 때마다, 약 $0.7 \mathrm{~V}$ 의 전압과 $50 \mathrm{nA}$ 의 전류를 생성하는데 성공하였다. 가장 최근에는 한국세라 믹기술원에서 Fig. 12 과 같이 압전 나노섬유를 기반으로 한 core-shell 구조의 압전 실(yarn)을 직조하여 장갑, 아대, 신발 깔창 등에 직접 바느질하여 신체 움직임에 따 른 출력 전압을 측정하였다28). 측정 결과 움직임에 따라 최대 $1.91 \mathrm{~V}, 0.38 \mu \mathrm{A}$ 의 출력 전압 및 전류을 얻었고 이 는 전극화 공정 최적화 및 모듈의 구조 설계를 통해 앞으 로도 계속 발전 될 것으로 전망된다.

\section{3. 결론}

플렉서블 압전 나노섬유를 이용한 에너지 하베스팅은 다른 발전 방법에 비해 주변 환경에 영향 없이 에너지를 얻기 쉽고, 친환경적이며, 기존은 벌크형 압전 에너지 변 환 소재와 유사한 에너지 변환 밀도 수준으로 기술이 발 달하고 있다. 또한 주위 환경에 관계 없이 일정하게 에너 
지를 얻을 수 있으며 에너지의 고갈에 대한 걱정 없이 다 양한 기계적 에너지를 전기적 에너지로 변환할 수 있다는 많은 장점을 가지고 있다. 플렉서블 압전 나노섬유 기반 의 에너지 변환 소재는 높은 에너지 변환 효율과 응용 가 능성을 높이기 위해 다양한 고성능 압전 세라믹을 나노섬 유화 하였고, 변환 모듈에 사용되는 전극 소재, 전극 형 태를 조절하고, 변환모듈을 디자인하여 에너지 변환소재 의 출력을 증가 시키기 연구가 진행되었다. 하지만 대부 분의 플렉서블 압전 나노섬유는 $\mathrm{PVDF}-\mathrm{TrFE}$ 고분자를 단독으로 사용되고 있으며, 최근에서야 압전 세라믹인 $\mathrm{PZT}$ 또는 $\mathrm{BNT}$ 계열 둥이 복합화된 나노섬유 연구가 진 행되는 단계이다. 하지만 실제 우리 실생활에서 사용하기 에는 아직도 에너지 변환 효율이 낮은 상황으로 추가적인 기술 개발이 절실히 요구된다. 특히 웨어러블 전자기기의 수요 증가는 플렉서블한 에너지변환 소재의 높은 에너지 변환 효율을 요구할 것이며 이 요구를 해결하기 위해 고 성능 압전 나노섬유는 분명 유망한 에너지 변환 소재가 될 것이다. 또한 웨어러블 압전 나노섬유에 대한 연구는 아직 초기 단계이기 때문에 원천 기술 확보 및 국가의 경 제력 향상을 위한 국가 차원의 연구비 지원과 상용화 연 구 발전을 위한 기업, 학교, 연구소의 산 · 학 · 연 간의 공 동연구 추진 및 산업에 적용하기 위한 노력이 지속되어야 할 것으로 전망된다.

\section{참고문헌}

1. L.Z. Broderick, B. R. Albert, B. S. Pearson, L. C. Kimerling, J. Michel, "Design for energy: Modeling of spectrum, temperature and device structure dependences of solar cell energy production," Sol. Energ. Mat. Sol. C., 136, 48-63 (2015).

2. M. Cheng, Y. Zhu, "The state of the art of wind energy conversion systems and technologies: A review," Energ. Convers. Manage., 88, 332-347 (2014).

3. S. Yilmaz, H. Selim, "A review on the methods for biomass to energy conversion systems design," Renew. Sust. Energ. Rev., 25, 420-430 (2013).

4. N. Chakhchaoui, H. Ennamiri, A. Hajjaji, A. Eddiai, M. Meddad, Y. Boughaled, "Theoretical modeling of piezoelectric energy harvesting in the system using technical textile as a support," Polym. Adv. Technol., 28, 1170-1178(2017).

5. L. Jiang, Y. Yang, R. Chen, G. Lu, R. Li, D. Li, M. S. Humayun, K. K. Shung, J. Zhu, Y. Chen, Q. Zhou, "Flexible piezoelectric ultrasonic energy harvester array for bio-implantable wireless generator," Nano Energy, 56, 216-224 (2019).

6. M. Byun, "Poly(vinylpyrrolidone)-modification of sol-gel films for flexible piezoelectric energy harvesting systems," Thin. Solid. Films, 663, 31-36 (2018).

7. F. Chang, M. Dommer, C. Chang, L. Lin, "Piezoelectric nanofibers for energy scavenging applications," Nano Enegry, 1, 356-371(2012)

8. M. Wu, Y. Wang, S. Gao, R. Wang, C. Ma, Z. Tang, N. Bao, W. Wu, F. Fan, W. Wu, "Solution-synthesized chiral piezoelectric selenium nanowires for wearable self-powered human-integrated monitoring," Nano Energy, 56, 693-699 (2019).

9. S. Tiwari, A. Gaur, C. Kumar, P. Maiti, Enhanced piezoelectric response in nanoclay induced electrospun PVDF nanofibers for energy harvesting," Energy, 171, 485-492 (2019).

10. X. Xue, Z. Qu, Y. Fu, B. Yu, L. Xing, Y. Zhang, "Self-powered electronic-skin for detecting glucose level in body fluid basing on piezo-enzymaticreaction coupling process," Nano Energy, 26, 148-156 (2016).

11. Global markets and technologies for nanofibers," BCC Research (2019)

12. J. H. Yang, T. Ryu, Y. Lansac, Y. H. Jang, B. H. Lee, "Shear stress-induced enhancement of the piezoelectric properties of PVDF-TrFE thin films," Org. Electron. 28, 67-72 (2016).

13. L. Wang, J. Zhu, X. Zou, F. Zhang, " $\mathrm{PbTiO}_{3}$ - P(VDFrTeFE) composites for piezoelectric sensors," Sensor. Actuat. B-Chem., 66, 266-268 (2000).

14. J. S. Yun, C. K. Park, Y. H. Jeong, J. H. Cho, J.-H. Paik, S. H. Yoon, K.-R. Hwang, "The Fabrication and Characterization of Piezoelectric PZT/PVDF Electrospun Nanofiber Composites," Nanomater. Nanotechno. 149. 127-133(2017).

15. X. Xu, Z. Wu, L. Xiao, Y. Jia, J. Ma, F. Wang, L. Wang, M. Wang, H. Huang, "Strong piezo-electrochemical effect of piezoelectric $\mathrm{BaTiO}_{3}$ nanofibers for vibration-catalysis," J. Alloy. Compd., 762, 915-921 (2018). 


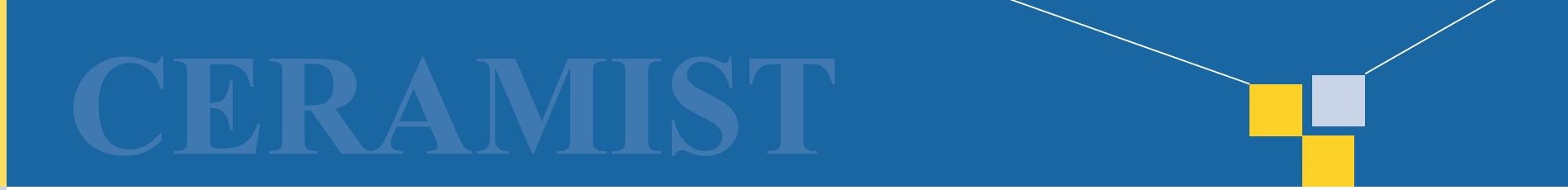

특 집 미상현, 윤지선

16. S. Bairagi, S. W. Ali, "A unique piezoelectric nanogenerator composed of melt-spun PVDF/KNN nanorod-based nanocomposite fibre," Eur. Polym. J., 116, 554-561 (2019).

17. J. H. Jung, M. Lee, J.-I. Hong, Y. Ding, C.-Y. Chen, L.-J. Chiu, Z. L. Wang, "Lead-Free $\mathrm{NaNbO}_{3}$ Nanowires for a High Output Piezoelectric Nanogenerator" ACS Nano, 5, 10041-10046 (2011).

18. C. Beak, J. H. Yun, J. E. Wang, C. K. Jeong, K. J. Lee, K.-I. Park, D. K. Kim, "A flexible energy harvester based on a lead-free and piezoelectric BCTZ nanoparticle-polymer composite," Nanoscale, 8, 17632-17638 (2016).

19. Q. Chi, G. Liu, C. Zhang, Y. Cui, X. Wang, Q. Lei, "Microstructure and dielectric properties of BZTBCT/PVDF nanocomposites," Results. Phys., 8, 391396(2018).

20. J. S. Yun, C. K. Park, J. H. Cho, J.-H. Paik, Y. H. Jeong, J.-H. Nam, K.-R. Hwang, "The effect of PVP contents on the fiber morphology and piezoelectric characteristics of PZT nanofibers prepared by electrospinning," Mater. Lett., 137, 178-181(2014)

21. W. Deng, T. Yang, L. Jin, C. Yan, H. Huang, X. Chu, Z. Wang, D. Xiong, G. Tian, Y. Gao, H. Zhang, W. Yang, "Cowpea-structured PVDF/ZnO nanofibers based flexible self-powdered piezoelectric bending motion sensor towards remote control of gestures," Nano Energy, 55, 516-525(2019)

22. J. S. Yun, C. K. Park, Y. H. Jeong, J. H. Cho, J.-H. Paik, S. H. Yoon, K.-R. Hwang, "The Fabrication and Characterization of Piezoelectric PZT/PVDF Electrospun Nanofiber Composites," Nanomater. Nanotechno. 149. 127-133(2017).
23. N. Nandini, M. Krishan, A.V. Suresh, H. N. N. Murthy, "Effect of MWCNTs on piezoelectric and ferroelectric properties of KNN composites," Mat. Sci. Eng. B, 231, 40-56(2018).

24. S. H. Ji, J. H. Cho, Y. H. Jeong, J.-H. Paik, J. D. Yun, J. S. Yun, "Flexible lead-free piezoelectric nanofiber composites based on BNT-ST and PVDF for frequency sensor applications," Sensor. Actuat. A-Phys., 247, 316-322(2016).

25. S. H. Ji, J. S. Yun, "Fabrication and Characterization of Aligned Flexible Lead-Free Piezoelectric Nanofibers for Wearable Device Applications," Nanomaterials, 8,206-213(2018).

26. Q. Jing, S. Kar-Narayan, "Nanostructured polymerbased piezoelectric and triboelectric materials and devices for energy harvesting applications," J. Phys. D: Appl. Phys., 51 303001-303023(2018).

27. C. R. Bowen, L. J. Nelson, R. Stevens, M. G. Cain, M. Stewart, "Optimisation of interdigitated electrodes for piezoelectric actuators and active fibre composites," J. Electroceram. 16, 263-269(2006).

28. S. H. Ji, Y. S. Cho, Y. J. Yun, "Wearable core-shell piezoelectric nanofiber yarns for body movement energy harvesting," Nanomaterials, 9, 555-564(2019).

29. L. Gu, N. Cui, L. Cheng, Q. Xu, S. Bai, M. Yuan, W. Wu, J. Liu, Y. Zhao, F. Ma, Y. Qin, Z. L. Wang, "Flexible Fiber Nanogenerator with 209 V Output Voltage Directly Powers a Light-Emitting Diode," Nano Lett., 13, 91-94(2013).

30. C. K. Jeong, L. Lee, S. Han, J/ Ryu, G.-T. Hwang, D. Y. Park, J. H. Park, S. S. Lee, M. Byun, S. H. Ko, K. J. Lee, "A Hyper-Stretchable Elastic-Composite Energy Harvester," Adv. Mater. 27, 2866-2875(2015).

○。 윤 지 선

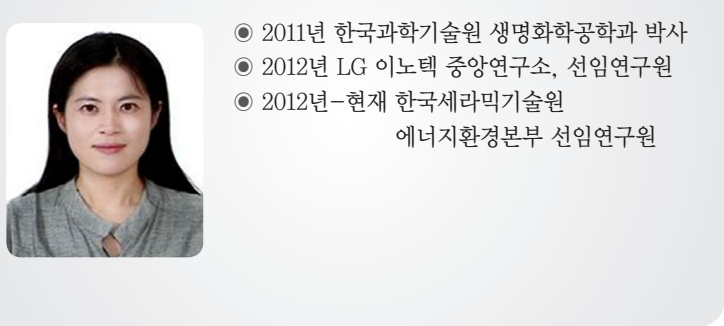

(0) 2015년 경남대학교 과학교육과 학사 ○ 2017년 경남대학교 첨단공학과 석사

- 2015년-현재 한국세라믹기술원 에너지환경본부 연구원 